УДК $745 / 749$

Татьяна Олеговна Махова,

кандидат педагогеских наук, доцент, доцент кафедры архитектуры, дизайна и экологии,

Сочинский государственный университет,

Сочи, Россия,

ORCID: 0000-0003-0025-8354;

Киба Ольга Владимировна,

старший преподаватель

кафедры архитектуры, дизайна и экологии,

Сочинский государственный университет,

Сочи, Россия

\title{
ЦВЕТ КАК ВАЖНЕЙШЕЕ СРЕДСТВО ПРЕОДОЛЕНИЯ ПАРАДИГМАЛЬНЫХ ИЗМЕРЕНИЙ В ОБЩЕНИИ ДИЗАЙНЕРА И ПОТРЕБИТЕЛЯ
}

Аннотация. В статье рассматриваются принципы гармонизации цветов и закономерности их комбинаций в аспекте экологического подхода в дизайне среды. Экологический подход к проектированию представляет собой определенный срез мыслей и образ действий, задающий ориентацию проектной деятельности.

Экологический и художественно-образные аспекты, используемые с целью обогащения возможностей дизайнерского творчества, являются важнейшими компонентами синтетического проектного мышления. Создание специальных эвристических методов проектирования на основе раскрытия синтетического характера проектного мышления позволяет использование природной экосистемы для создания целостности объекта дизайна. Популярность данного метода при проектировании достигается многими факторами, с его помощью воссоздается природная, гармоничная среда, которая включает признаки и закономерности цветовых гармоний на основе различных природных биосистем и их воздействие на 
эмоциональное состояние человека в общественном интерьере. Современный интерес к цвету почти целиком носит визуальноматериальный характер и игнорирует смысловые и духовные переживания. Проектируя общественные пространства нужно учитывать, что дизайн опирается на научное знание, находясь на перекрестке многих дисциплин, он приобщает к ним всех, кто следует его законам и проектирует, соотнося с ними результаты своей деятельности. Экологический подход к проектированию, основанный на когнетивном процессе осмысления природной формы, демонстрирует преодоление парадигмальных измерений при создании дизайна интерьера.

Когнитивное отношение к природной среде формирует способность человека преобразовывать мир по законам красоты, целесообразности и не отрываться от природных корней, чутко относиться к среде обитания, являться ее неотъемлемой частью. При этом имеется в виду, что указанные установки не отрываются от задач креативных поисков современных инновационных решений. В этом реализуется неисчерпаемый творческий потенциал гармонизирующей проектной деятельности. Проектирование становится экспрессивной, коммуникативной формой истолкования окружающего мира и общества, его ментальной, сенсорной и духовной деятельности.

Ключевые слова: дизайн интерьера, цветовые отношения, парадигма, проектирование интерьера кафе.

Вступление. Сложившиеся в течение тысячелетий связи цветов с определенными явлениями, предметами, понятиями, событиями сформировали психологическое отношение человека к цвету [8].

Эстетическое восприятие цвета человеком подтверждает признанную способность цвета гармонизировать как произведение искусства, так и цветовую среду, окружающую человека. Сила эстетического воздействия цветовых сочетаний кроется как в физиологическом восприятии, так и в осознанном 
индивидуальном отношении человека к цвету. Считается, что гармоничные цветовые сочетания позволяют человеку испытывать чувство радости, а потеря цвета или дисгармоничные сочетания создают противоположные ощущения.

Постановка проблемы. Современный интерес к цвету почти целиком носит визуально-материальный характер и игнорирует смысловые и духовные переживания. Это поверхностная, внешняя игра с метафизическими силами. Цвет, излучаемая им сила, энергия, действуют на нас положительно или отрицательно независимо оттого, сознаём мы это или нет. Старые мастера, создававшие витражи, использовали цвет для создания неземной, мистической атмосферы и медитаций молящихся, переносящих их в мир духовной реальности. Цвет действительно должен переживаться не только зрительно, но психологически и символически. Природа цвета может изучаться с разных позиций. На основе цветовых впечатлений возникают объективные и субъективные ассоциации.

Анализ последних исследований и публикаций. Данную проблематику рассматривает Н. В. Алгазина в своем пособии «Цветоведение и колористика» [1]. Вторая часть пособия, «Гармония цвета», выпущенная в 2014 г., знакомит студентов с вопросами, связанными с эмоциональным воздействием цвета на человека, рассматриваются признаки и закономерности цветовых гармоний. В пособии затрагиваются и вопросы, касающиеся эффектов разнообразного воздействия цвета, возможность управлять им. При этом проблемы субъективного суждения о цвете являются особенно важными в художественном воспитании будущего специалиста в области дизайна среды.

Иоханнес Иттен в своей книге «Искусство цвета» выделяет три эстетических аспекта воздействия цвета: конструктивное, экспрессивное и империческое. Следуя 
утверждению мастера, примем за истину то, что каждый из этих аспектов предполагает присутствие и двух других» [13].

А. Ефимов в своей книге « Цвет + форма: искусство XXXXI вв.: живопись, скульптура, инсталяция, лэнд-арт, дигиталарт» охарактеризовал данную проблему как то, что полихромия на плоскости таит в себе возможности рождения и разворачивания в пространстве реальной пластики [8].

Е. В. Жердев, опираясь на учебном пособии «Метафора в дизайне» [10] пишет, что при создании уникального объекта дизайна можно использовать метод метафоры. «Одним из художественных средств в решении такой сверхзадачи является метафора как наиболее универсальная категория языка, которая до настоящего времени не разработана на теоретическом уровне в дизайне. Ценностная инновационная значимость метафоры заключается в том, что она позволяет на основе переноса черт различных социокультурных и природных явлений жизни человека на утилитарную форму объекта достичь неожиданного, иногда парадоксального визуального эффекта, вызывающего обостренный интерес к вещи у потребителя. Метафорой лишь называют сам метод сравнения воображаемой модели с существующей средой. Понятие метафоры используется и когда речь идет о типологии как средстве художественного моделирования, когда основной категорией проектной типологии оказывается образ-тип. Двойственность этой категории отражает двойственный характер художественной модели, связанной с тем, что воображаемый объект предстает как осознанная художественная условность, обобщенно говоря, как художественная метафора, а не прямое изображение. Хотя на эмпирическом уровне интуитивно дизайнеры используют метафору как средство художественной выразительности» [10].

Подобными исследованиями занимается И. П. Кириенко. В своем учебном пособии «Проектная культура регионального экологического дизайна» [15] она рассматривает вопросы создания уникальной модели дизайна на основе природы 
родного края. «В контексте рассмотрения вопросов проектной культуры регионального экологического дизайна путеводную роль играет высказывание академика Д. С. Лихачева: «На пороге третьего тысячелетия речь должна идти не только о выживании «человеческих особей», но и о сохранении человеческой культуры в ее нравственных, эстетических, научных традициях» [15]. «Понимание триединой сущности, обладающей свойством быть прошлым, быть настоящим, быть будущим» связано с непрерывностью культурных процессов и развития в каждом регионе России «феномена места» [15].

В существующих природных условиях заложены возможности множества вариаций, которые путём анализа функциональных аспектов могут использоваться в построении альтернативных проектных решений. В результате этого региональная среда обозначается как источник идей специальной области проектирования - обитание как экологическая деятельность. При таком подходе коренным образом меняется роль проектной деятельности, которая становится средством воспроизведения интеллектуальнокультурного потенциала общества. Этим, по существу, утверждается взгляд на дизайн как на мост, соединяющий новую цивилизационную культуру с накопленным ранее уникальным ее достоянием [15].

Закономерности цветовых гармоний на основе различных природных биосистем создаются для того, чтобы преодолеть парадигмальные измерения при создании дизайна интерьера. В. Папанек сформулировал четыре важнейших принципа дизайна, которые можно считать основополагающими:

1. в настоящее время невозможен и неприемлем дизайн, связанный с социологическими, психологическими аспектами жизни и экологией окружения; 
2. дизайнерское проектирование, как отдельных предметов, так и окружающей среды, должно вестись междисциплинарными коллективами;

3. междисциплинарный коллектив должен включать также как потребителей (пользователей), так и тех, кто производит вещи, разработанные дизайнерами;

4. биология, бионика и связанные с ними сферы деятельности дают дизайнерам новое, плодотворное понимание проблем; дизайнеры должны находить аналогии, используя биологические прототипы и системы дизайнерского подхода, взятые из таких областей как этология, антропология и морфология.

Цель статьи - проанализировать цвет как средство преодоления парадигмальных измерений в общении дизайнера и потребителя, осветить наиболее распространенные принципы и цветовых композиций в гамонизацархитектурной колористике.

Основной целью в цветовом проектировании является создание интерьера на основе поиска эвристических проектных решений и возможность использования природо-сообразных бионических форм, опирающихся на образно-эмоциональный аспект.

Цветопсихология в настоящее время уделяет особое внимание серьезному изучению и систематизации знаний о силе воздействия цвета на человека. Гармония природных цветов отражается в произведениях художников, сочетания естественных цветов влияют на выбор искусственных сочетаний, вносимых человеком в архитектурное и природное окружение.

В архитектурной колористике наиболее распространены принципы гармонизации цветовых композиций по Э. Веберу, по Дж. Мэнделу, по Д. Джадду и Г. Вышецки. В основу системы Д. Джадда и Г. Вышецки положено их творческое кредо: «...лучшее руководство по гармонизации - природа». 


\section{Изложение основного материала. Проектируя} общественные пространства, нужно учитывать, что цвета в природе не существует в отрыве от формы, так же как не существует бесцветной формы. Каждое из свойств формы стереометрия, масса, фактура, цвет и др. - имеет бесконечное количество состояний, совокупность которых определяет визуальное ощущение конкретной формы. При изменении состояний названных свойств формы меняется ее визуальное ощущение, которое может быть обусловлено изменением лишь одного ее свойства - цвета [8].

Дизайн как вид проектного творчества и техническая эстетика как наука о дизайне в своей специфике мышления используют неиссякаемый источник интуитивного знания. Но, тем не менее, в современном обществе снижается понимание художественно-образной содержательности и духовной значимости эстетического компонента искусственной и естественной окружающей среды. В дизайне укореняется сугубо прагматический подход, заключающийся в усвоении узкого набора навыков, необходимых для проектирования ограниченного круга объектов. Именно поэтому важнейшими компонентами синтетического проектного мышления являются экологический и художественно-образный аспекты, используемые с целью обогащения возможностей дизайнерского творчества. Особый интерес для раскрытия синтетического характера проектного мышления представляют идеи целеустремленного генерирования новых методик и создание на их основе специальных эвристических методов проектирования [15].

«То обстоятельство, что во всех слоях культуры художественно-творческая деятельность имеет интегративный, синтетический характер, ставит искусство на особое место в культуре общества» (М. С. Каган). На этом основании можно обозначить, что единое комплексное проектирование составляет в целом единую проектную культуру, вбирает в себя 
дизайнерскую деятельность, отвечающую за форму и образ объектов, научно-исследовательскую и технологическую. В проектной культуре дизайна основными становятся две линии развития: 1 - художественное конструирование различных средовых объектов, 2 - включение их в контекст культуры и экологии. Таким образом, проектная культура является частью более широкого явления современной многоукладной культуры, наряду с народной, городской, массовой, церковной, гуманитарной, технической и т. д. [5].

Теоретики проектной культуры дизайна рассматривают эту область под разными ракурсами, дополняющими друг друга. В. Ф. Сидоренко определил в отношении к каноническому типу культуры «проектную культуру как тип культуры». Сложные взаимоотношения дизайнера с объектом проектирования реализуют степень его проникновения в ценностный пласт культуры; проектируемый объект имеет объективную возможность адаптироваться в экологию [27].

Проектирование становится экспрессивной, коммуникативной формой истолкования окружающего мира и общества, его ментальной, сенсорной и духовной деятельности. Это ставит будущего дизайнера в центр культурологических, психологических, экономических, мировоззренческих и других проблем социума, вызывая необходимость синтетического подхода к оценке действительности [16].

Материально-духовная культура может быть выражена только средствами искусства, в том числе дизайна, и в приближении к эколого-культурному контексту проектирования, который граничит с фантазийным контекстом. В нем выявляется эмоционально-смысловое, личное мировосприятие. При такой постановке вопроса многое зависит от точности выявления потребностей, a, следовательно, от социологических (а точнее, социосемиотических) служб. Социологи и социосемиотики, в свою очередь, утверждают, что такой учет будет действительно точным, если выявляет не 
только объективируемые утилитарные потребности, пусть даже специализированные, но и все многообразие культурных ценностных ориентаций, с трудом или вообще не поддающихся объективации».

В этом случае, среди многих других, на повестку дня выдвигаются два важнейших для дизайна вопроса: 1 - задачи поиска эвристических проектных решений; 2 - возможность использования в проектировании природо-сообразных бионических форм, опирающихся на образно-эмоциональный аспект [17].

Первая задача может быть решена посредством применения методики, предложенной в своей диссертационной работе Б. И. Клубиковым. Суть ее заключается в том, что эвристические проблемы, рассматривающиеся ранее применительно к инженерному творчеству, изобретательству и прогнозированию, были перенесены в область дизайна. Они послужили основой для разработки проблем оптимизации процесса принятия проектного решения, а также процесса творческого поиска путем включения в практику дизайна системы методических средств, обеспечивающих стимуляцию творческого мышления и активизацию деятельности. Конкретным результатом его работы стала методика эвристического поиска в процессе принятия проектного решения. Его целью является развитие и стимулирование объективными научными методами скрытых творческих возможностей дизайнеров, формирование основ интенсификации, самоуправления процессом проектирования. Процесс проектирования соответственно разделен на несколько последовательных этапов: этот путь логического выстраивания последовательности действий приводит, в конечном счете, к организации сценариев проектных событий настоящего и будущего, т. е. от существующего положения до прогностического моделирования футуристического состояния средового дизайна. Следуя сценарному методу проектирования 
(Рябушин, Сидоренко, Пузанов и др.), дизайнер погружается в быстро изменяющийся мир настоящего и будущего, драматизирует, иллюстрирует и режиссирует возможности дизайна вплоть до создания футуристических его моделей. Однако указанный метод не решает проблемы проектирования средовых объектов с учетом междисциплинарных интересов реальной дизайнерской ситуации - философии, психологии, культурологи, этики, естествознания и т. д., словом, всего того, с чем реально сталкиваются двусторонне ориентированные задачи глобализации и (одновременно) регионализации современной культуры. Разнообразие духовно-эстетических смыслов последней требует эмоционально-образной включенности дизайнера в процесс творчества. Не случайно во всем мире нарастает интерес к экологизации обучения. Природа естественно близка и органично воспринимаема всеми, важно только, чтобы ее явления адекватно воспринимались в истолковании художников-дизайнеров различных мировоззрений и культур. Именно это входит в суперзадачу экологически ориентированного проектирования [17]. Синтез естественно-природного (образно-эмоционального) и эвристического - это альфа и омега не только процесса познания, но и проектной деятельности. Под этим углом необходимо тщательно прослеживать различные точки зрения на творчество и его организацию, на возможность стимулирования процесса от простых до самых сложных проектных решений [18]. Достаточно вспомнить предложенные Ю. С. Лебедевым в книге «Архитектура и бионика» такие аспекты исследования живой природы, как:

- единство живого организма и окружающей среды как результат действия механизма приспособляемости;

- единство формы и функции в живой природе;

- развитие от простого к сложному, от примитивного к совершенному в процессе исторического развития и роста;

- законы компенсации и корреляции; 
- закон минимума, закон конвергенции т. д.

C подобных позиций подходили к проблемам формотворчества многие теоретики дизайна. В труде Е. Н. Лазарева «Бионические принципы архитектурного анализа и моделирование жизнедеятельности биологических систем и их элементов» предметом бионики является изучение принципов построения функционирования живых систем для создания технических объектов [18].

В дизайнерском экспериментальном формотворчестве указанные методы и эвристические принципы творчества дополняют друг друга (рис.1-6; на рис.1-2 представлена трансформация натурных природных форм в объекты дизайна).

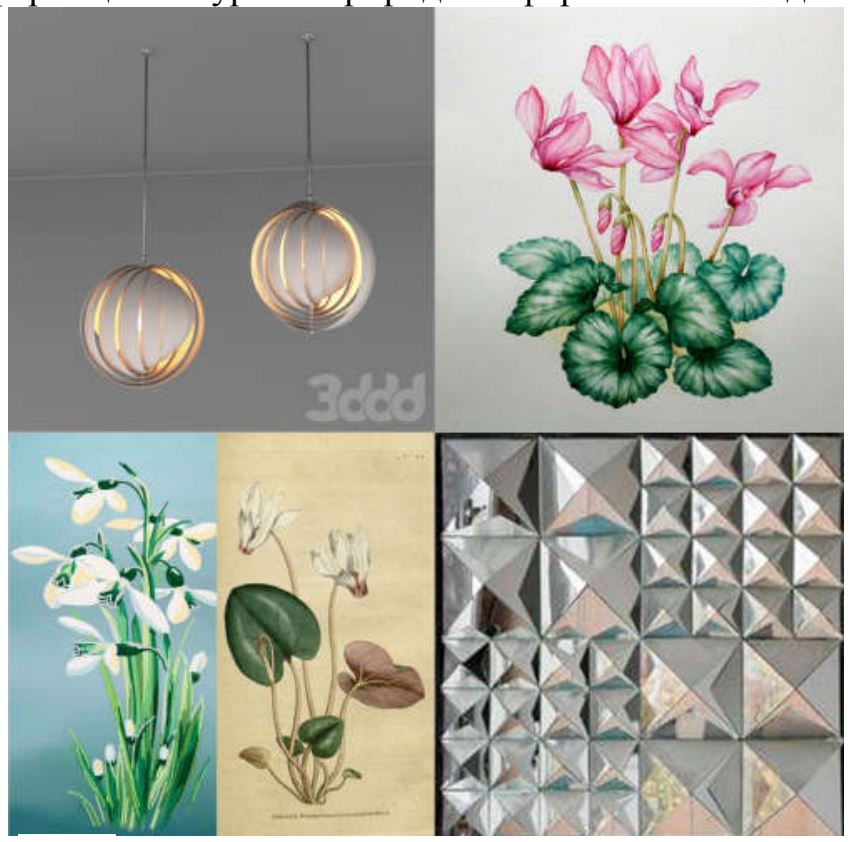

Рис. 1. Аналоговая подборка работ Вернера Пантона и художественных изображений первоцветов. Электронный ресурс. URL: https://www.pinterest.ru/ 
АРТ-платФОРМА. 2020. Вип. 1

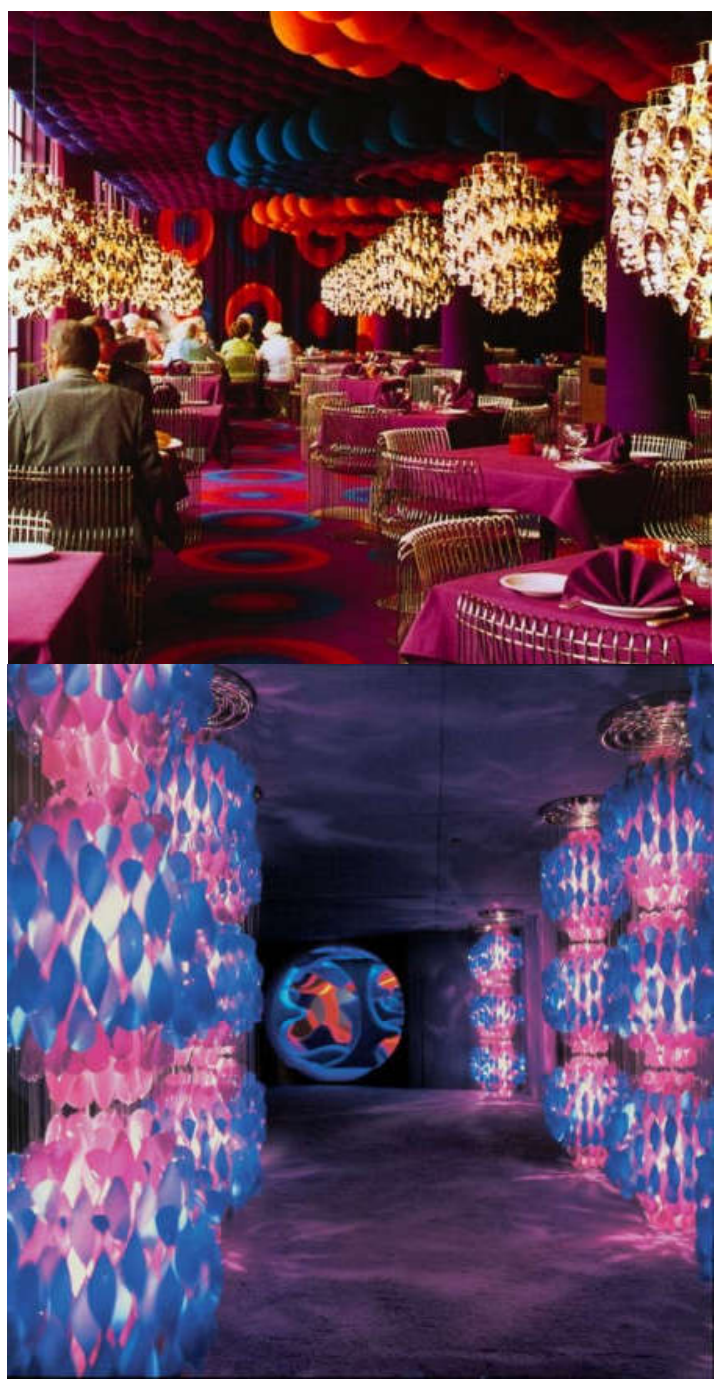

Рис.2. Аналоговый ряд дизайнера Вернера Пантона. URL: https://www.pinterest.ru/ 
С этих позиций их совместное развитие можно квалифицировать как комплексную систему подхода к формотворческому процессу посредством применения противоположно направленных методов проектирования. Если это удастся осуществить, обучение методам проектирования превращается в увлекательный, необыкновенно интересный и жизненно необходимый процесс. В нем заключается суть синтеза логического и образно-интуитивного методов мышления [27].
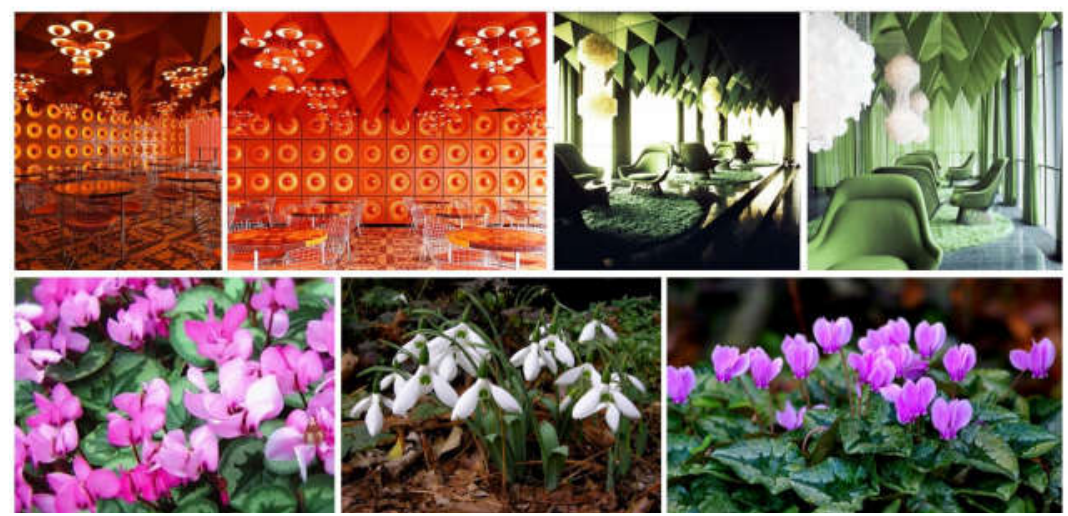

Рис.3. Использование аналогового ряда для создания концептуального интерьера дизайнером Вернером Пантоном

В условиях активно набирающего обороты современного техногенного мира в наше время меняются подходы ко всем областям человеческой жизни. К тому же, с развитием технологий в мире появляется множество новейших материалов: сверхлёгких, самовосстанавливающихся, огнеупорных, экологичных, сверхпрочных и множество других. С их помощью было созданное множество шедевров архитектуры и дизайна [2].

Помимо того, было создано множество программ, упрощающих работу дизайнеров и архитекторов. Новые методы 
и подходы к проектированию очевидны, и они распространяются на все сферы деятельности. И в проектировании повсеместно применяются инновационные методы и программы для визуализации готовых идей.
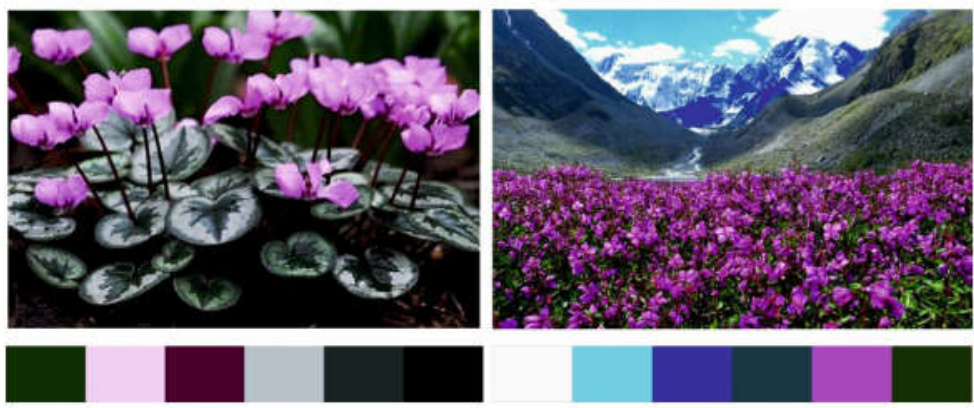

Рис.4. Колористический ряд на основе аналогов

Не удивительно, что у современного человека, постоянно обитающего в такой технологичной и качественной среде, высокие запросы к окружающим его пространствам. Поэтому каждый интерьер должен быть комфортным и отвечать всем запросам посетителя. Однако, несмотря на развитие прогресса, появление новых технологий, на все плюсы для существования современного общества, у человека, в связи с этим, появляется и некоторые проблемы. Например, жизнь становится серой и тусклой, лишённой романтики и ярких красок. Большинство людей, находясь в круговороте жизни, чувствуют накапливающуюся усталость и стресс. В результате, у человека, живущего в техногенной среде современных городов, возникает подсознательное влечение к чему-то новому, яркому и экзотичному. Это неудовлетворённая тяга к путешествиям, впечатлениям и новым открытиям. Адаптированная к условиям и принципами нынешнего времени, она, тем не менее, существует и формирует потребности человека, на которые и следует ориентироваться в выборе темы 
концептуального заключающейся в разработке интерьеров общественных пространств, способных максимально удовлетворить подобные запросы будущих клиентов [2].



Рис.5. Интерьеры кафе «Первоцвет»

В дизайне окружающей среды принцип выбора цветовой гармонии строится на мягких и контрастных цветовых отношениях, характеристики цветового восприятия, на основе ассоциаций, принятых во внимание при проектировании. Наиболее актуально это отражается при создании общественного интерьера. Повышение интереса современного, требовательного потребителя к проведению отдыха в местах общественного питания с качественным обслуживанием и необычным дизайном мотивирует дизайнера на создание интерьера с использованием природо-сообразных бионических форм, опирающихся на образно-эмоциональный аспект.

Использование цвета всегда было важным компонентом в процессе организации тематической среды человека. Сегодня это особенно важно в контексте значительного расширения типологии объектов в объектно-пространственной среде, в том числе появления новых функциональных усложнений и модернизации существующих. В то же время количественное и качественное усложнение среды, окружающей человека, постоянно увеличивается. В такой ситуации особую 
ответственность приобретает роль профессионала, которая включает в себя такой важный компонент, как колористический. На практике адекватная оценка цвета выступает как активное средство эмоционального воздействия на человека [1].

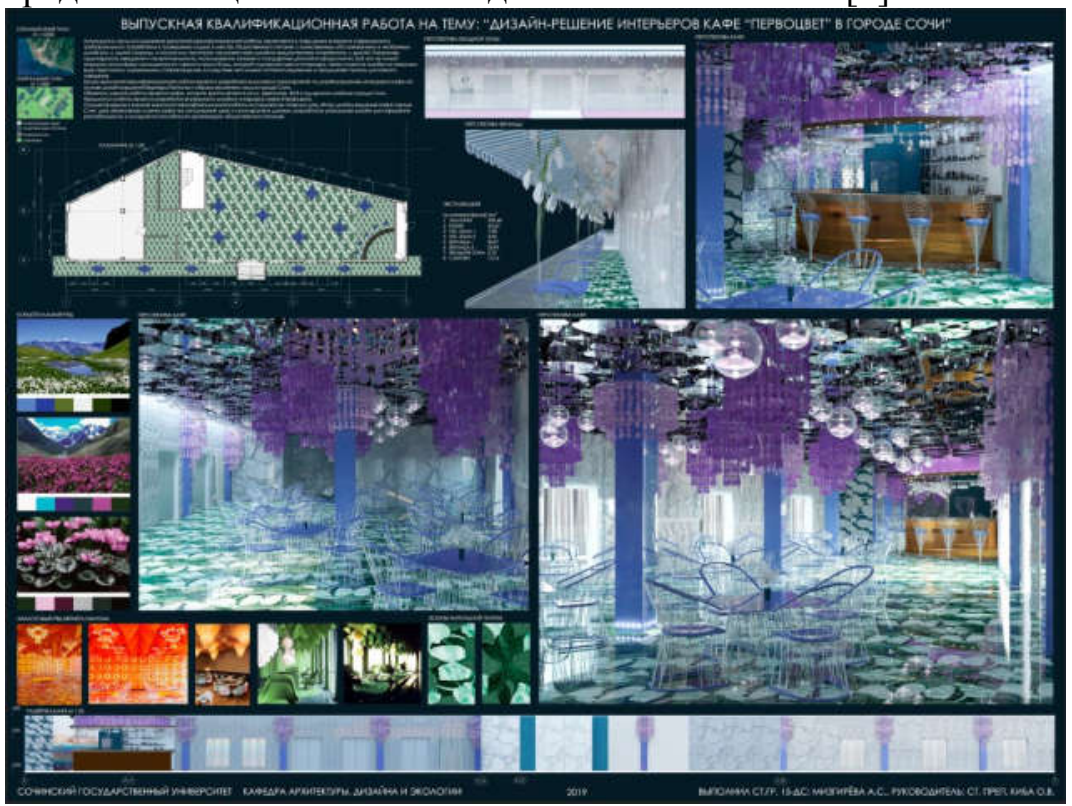

Рис.6 Дизайн-проект кафе «Первочявет»

Выводы. В рамках данного исследования студентами Сочинского государственного университета, использующими экологический подход к проектированию, в частности на основе поиска эвристических проектных решений и возможности использования природа-образных бионических форм, опирающихся на образно-эмоциональный аспект, был разработан дизайн-проект интерьера кафе (рис. 5-6). Весна в Сочи начинается еще зимой. Не успеют облететь листопадные деревья, как уже появляются первоцветы. Подснежники на Новый год, как в сказке, - в Сочи все это возможно: в начале 
января в лесах уже можно встретить первые весенние цветы. Этот образ был взят за основу при формировании дизайнконцепции кафе «Первоцвет», разработанной студентами Сочинского государственного университета (рис. 6). Для создания проекта данного кафе была проведена работа по анализу историко-культурной среды города. За основу концепции и главной идеи проекта был взят уникальный стиль Вернера Пантона, основнный на использовании природной экосистемы и ее воздействии на эмоциональное состояние человека в общественном интерьере.

Цветовые отношения в интерьере строятся на основе перехода природных тонов в пейзажах альпийских лугов Кавказского заповедника. В результате был построен обширный цветовой диапазон, который используется в интерьере. На территории города много достойных заведений, но они лишены такой передачи художественного образа, которую может предложить «Первоцвет», кафе действительно окунает в этот таинственный и яркий мир природной экосистемы.

Популярность данного метода при решении интерьера достигается многими факторами. С его помощью воссоздается природная, гармоничная среда, это достигается путем сочетания художественных деталей, оттенков, элементов декора, материалов отделки.

Современники излишне урбанизировали свою повседневную жизнь, живут в бетоне и стекле, хотя тяга к экологии и природе в целом неоспорима. Головы и сознание людей «запыляются» информационным ураганом, а источник наслаждения и морального отдыха, как всегда, где-то рядом.

Следовательно, экологический подход к проектированию представляет собой определенный срез мыслей и образ действий, задающий ориентацию проектной деятельности. 
Человек всегда черпал идеи, наблюдая за природой. Еще в конце XV в. Леонардо да Винчи сказал: «Те, кто изучают только авторов, а не произведения природы, те в искусстве внуки, а не сыновья природы - наставительницы хороших авторов...», и еще: «Эта милостивая природа позаботилась так, что ты во всем мире найдешь чему подражать. Живописец, бессмысленно срисовывающий, руководствуясь практикой и суждением глаза, подобен зеркалу, которое подражает в себе всем противопоставленным ему предметам, не обладая знанием их» [10]. 
Когнитивный процесс осмысления регионального ландшафта способен помочь почувствовать оригинальность и самобытность природного комплекса, в который органически должны включаться объекты дизайна. Этому способствует дизайн-проектирование, использующее характерные черты искусственной и естественной среды через образную метафору, когда в основе восприятия и воспроизведения окружающего мира лежит принцип уподобления. С одной стороны, дизайн ставит своей целью повышение комфорта средового окружения и включает в себя круг проблем, связанных с социальными, социально-экономическими, эргономическими, техническими и эстетическими аспектами развития культуры. С другой стороны - его интеллектуальный и творческий ресурс должен быть направлен на устранение предпосылок экологического кризиса, т. е. на развитие духовной связи между людьми, сообществами и окружающей природой, достигая гармонического единства.

Когнитивное отношение к природной среде формирует способность человека преобразовывать мир по законам красоты, целесообразности и не отрываться от природных корней, чутко относиться к среде обитания, являться ее неотъемлемой частью. При этом имеется в виду, что указанные установки не отрываются от задач креативных поисков современных инновационных решений. В этом реализуется неисчерпаемый творческий потенциал гармонизирующей проектной деятельности [2].

Экологический подход к проектированию, основанный на когнитивном процессе осмысления природной биосистемы, демонстрирует преодоление парадигмальных измерений при создании дизайна-интерьера.

\section{Литература}

1. Алгазина H. Цветоведение и колористика. Часть II. Гармония цвета: учебное пособие. Омск: Омский 
государственный институт сервиса, Омский государственный технический университет, 2015. 188 с.

2. Быстрова T. Вещь, форма, стиль. Философия дизайна: учеб.-метод.пособи. 2-е изд., перераб. Екатеринбург: Изд-во Урал. ун-та, 2015. 128 с.

3. Ворошилов B. Топонимы Российского Черноморья (история и этнография в географических названиях). Майкоп: ОАО Полиграфиздат «Адыгея», 2007. 264 с.: ил.

4. Градостроительство России XXI века: сб. науч. статей PAАCH. Москва: РАACH, 2001. 268 с.

Дизайн: иллюстр. словарь-справочник / Г. Минервин.

Москва: Архитектура-С, 2004. 283 с.: ил.

5. Ермолаев $A$. О реальности профессии архитекторадизайнера. Москва: Архитектура-С, 2004. 208 с.: ил.

6. Ефремов Ю. Тропами горного Черноморья. Москва: Гос. изд-во географ. лит-ры, 1963. 404 с.: ил.

7. Ефимов А. Цвет + форма: искусство 20-21 веков: живопись, скульптура. инсталляция, лэнд-арт, дигитал-арт. Москва: Буксмарт, 2014. 615 с.: ил.

8. Желондиевская Л. Эмоции графики. Изобразительные и выразительные возможности графических Метафорическая образность в дизайне. Москва: МСХА, 2004. 227 с.: ил.

9. Жердев E. Метафора в дизайне: Учеб. Пособие. Издание 2-е, переработанное и дополненное. Москва: Архитектура-С, 2010. 464 с., ил.

10. Зайцев А. Наука о цвете и живопись. Москва: Искусство, 1986. 158 с.: ил.

11. Ивянская И. Мир жилища. Москва: Дограф. 2000. 297 с.: ил.

12. Иттен И. Искусство цвета. Москва: Д. Аронов, 2001. 96 с.: ил.

13. Калиничева $M$.Научная школа эргодизайна ВНИИТЭ: предпосылки, исто-ки, тенденции становления: моногр. Москва: ВНИИТЭ; Оренбург: ИПК ГОУ ОГУ, 2009. 368 с.: ил. 
14. Кириенко И. Проектная культура регионального экологического дизайна: Учеб. Пособие. Сочи: РИЦ ФГБОУ ВПО «СГУ», 2014. $116 \mathrm{c}$.

15. Кириенко И., Новиков А. Преемственность в системе непрерывной подготовки будущих дизайнеров. Метод «Ключ». Москва-Сочи: ООО Научно-проектный центр М. Калиничевой «Техническая эстетика», 2010. 125 с.: ил.

16. Кириенко И., Кириенко Ю. Морфологические особенности региональной природной среды Причерноморья как творческая основа креативного дизайна: Учеб. Пособие. Сочи: РИЦ СГУТиКД, 2011. 104 с.: ил.

17. Кириенко И. Преемственная безбарьерная подготовка дизайнера в условиях региональной культуры (на примере г. Сочи). Автореферат на соискание ученой степени кандидата искусствоведения. 17.00.06 - Техническая эстетика и дизайн. Москва: МГХПА им. С. Г. Строганова, 2011. 24 с.

18. Кириенко И., Махова Т, Быкадорова Е. Общественный объект в среде. Выставка: Учеб пособие. Сочи: РИЦ СГУ, 2013. 56 с.; ил.

19. Клее П. Педагогические эскизы. Москва: Д. Аронов, 2005. 71 с.: ил.

20. Курьерова Г. Экология предметного мира как стратегия дизайна в постиндустриальный период. Москва: ВНИИТЭ, 2008. $131 \mathrm{c}$.

21. Лоншакова Н., Солодько А. Природное и историкокультурное наследие Хостинского района города Сочи. Сочи: Популярная энциклопедия Сочинского Причерноморья, 2007. 111 с.: ил.

22. Мельников В. Мыслить рисунком. Уфа: Нефтегазовое дело, 2007. 102 с.: ил.

23. Михайлов $C$. Фирменный стиль как средство выражения «исторической памяти» города // Материалы 12-й Всерос конф. главных художников и главных дизайнеров городов. Москва: Союз дизайнеров России, 2009. Сс. 9-12. 
24. Михайлов C., Михайлова A. Основы дизайна: учебник для вузов под ред. С. М. Михайлова. Казань: «Дизайн-квартал», 2008. 288 с.: ил.

25. Полухина T. История Сочи в открытках и воспоминаниях. Москва: МЗ: Прогресс, 2009. 252 с.: ил.

26. Сидоренко В. Эстетика проектного творчества. Москва: ВНИИТЭ, 2007. $135 \mathrm{c}$.

27. Техническая эстетика и дизайн: Словарь. Москва: Академический проект; Культу-ра, 2012. 356 с.

28. Шевелев И. Визуальные и числовые образы реального мира. Основы гармо-нии. Москва: Луч, 2009. 359 с.: ил.

Тетяна Олегівна Махова, кандидат педагогічних наук, доцент, доцент кафедри архітектури, дизайну та екології,

Сочінський державний університет,

Сочі, Росія

ORCID: 0000-0003-0025-8354;

\section{Ольга Володимирівна Кіба}

старший викладач кафедри архітектури, дизайну та екології,

Сочінський державний університет, Сочі, Росія

\section{КОЛІР ЯК НАЙВАЖЛИВІШИЙ ЗАСІБ ПОДОЛАННЯ ПАРАДИГМАЛЬНИХ ВИМІРЮВАНЬ У СПІЛКУВАННІ ДИЗАЙНЕРА ТА СПОЖИВАЧА}

Анотація. У статті розглядаються принципи гармонізації кольорів і закономірності їх комбінацій в аспекті екологічного підходу в дизайні середовища. Екологічний підхід до проектування являє собою певний зріз думок і образ дій, що задає орієнтацію проектної діяльності. 
Екологічний i художньо-образні аспекти, які використовуються 3 метою збагачення можливостей дизайнерської творчості, $\epsilon$ найважливішими компонентами синтетичного проектного мислення. Створення спеціальних евристичних методів проектування на основі розкриття синтетичного характеру проектного мислення дозволяє використання природної екосистеми для створення цілісності об'єкта дизайну. Популярність даного методу при проектуванні досягається багатьма факторами, 3 його допомогою відтворюється природне, гармонійне середовище, яке включає ознаки й закономірності колірних гармоній на основі різних природних біосистем i їх вплив на емоційний стан людини в громадському інтер'єрі.

Сучасний інтерес до кольору майже цілком носить візуально-матеріальний характер та ігнорує смислові й духовні переживання.

Проектуючи громадські простори, потрібно враховувати, що дизайн спирається на наукове знання, перебуваючи на перехресті багатьох дисциплін, він долучає до них всіх, хто слідує його законам і проектує, співвідносячи з ними результати своєї діяльності.

Екологічний підхід до проектування, заснований на когнітивному процесі осмислення природної форми, демонструє подолання парадигмальних вимірів при створенні дизайну інтер'єру.

Когнітивне ставлення до природного середовища формує здатність людини перетворювати світ за законами краси, доцільності і не відриватися від природних коренів, чуйно ставитися до середовища проживання, бути його невід'ємною частиною. При цьому мається на увазі, що зазначені установки не відриваються від завдань креативних пошуків сучасних інноваційних рішень. У цьому реалізується невичерпний творчий потенціал гармонізуючої проектної діяльності. Проектування стає експресивною, комунікативною формою 
тлумачення оточуючого світу і суспільства, його ментальної, сенсорної та духовної діяльності.

Ключові слова: дизайн інтер'єру, колірні співвідношення, парадигма, проектування інтер'єру кафе

Tatyana O. Makhova, $\mathrm{PhD}$ in Pedagogical Sciences, Associate Professor, Associate Professor of the Department of architecture, design and ecology, Sochi State University, Sochi, Russia ORCID: 0000-0003-0025-8354;

Olga V. Kiba,

Senior lecturer of the

Departments of architecture, design and ecology

Sochi State University, Sochi, Russia

\title{
COLOR AS THE MOST IMPORTANT MEANS OF OVERCOMING PARADIGM DIMENSIONS IN COMMUNICATION BETWEEN THE DESIGNER AND THE CONSUMER
}

\begin{abstract}
The article discusses the principles of harmonization of colors and the laws of their combinations in the aspect of the ecological approach in the design of the environment. The ecological approach to design is a certain section of thoughts and a mode of action that sets the orientation of the project activity.

Ecological and artistic-figurative aspects used to enrich the possibilities of design creativity are the most important components of synthetic design thinking. The creation of special heuristic design methods based on the disclosure of the synthetic nature of project thinking allows the use of the natural ecosystem to create the integrity of the design object. The popularity of this method in design
\end{abstract}


is achieved by many factors, with its help a natural, harmonious environment is recreated, which includes the signs and patterns of color harmonies based on various natural biosystems and their impact on the emotional state of a person in a public interior.

The modern interest in color is almost entirely visualmaterial in nature and ignores semantic and spiritual experiences.

When designing public spaces, you need to consider thatdesign is based on scientific knowledge, being at the crossroads of many disciplines, he brings to them all who follow his laws and designs, correlating the results of his activities with them.

An ecological approach to design based on the cognitive process of understanding the natural form demonstrates overcoming paradigm measurements in creating interior design.

A cognitive attitude to the natural environment forms a person's ability to transform the world according to the laws of beauty, expediency and not break away from natural roots, to be sensitive to the environment, to be its integral part. At the same time, it is understood that these installations do not break away from the tasks of creative searches for modern innovative solutions. This implements the inexhaustible creative potential of harmonizing project activities. Designing becomes an expressive, communicative form of interpretation of the world and society, its mental, sensory and spiritual activities.

Key words: Interior design, color relationships, paradigm, design of the interior of he cafe.

\section{Reference}

1. Algazina N. Tsvetovedeniye i koloristika. Chast' II. Garmoniya tsveta: uchebnoye posobiye [Color science and color. Part II Harmony of color: study guide]. Omsk: Omsk State Institute of Service, Omsk State Technical University, 2015. 188 s. (in Russian)

2. Bystrova T. Veshch', forma, stil'. Filosofiya dizayna: ucheb.metod.posobiye [Thing, form, style. Design Philosophy: textbook.- 
method]. 2nd ed., Revised. Yekaterinburg: Publishing House Ural. University, 2015. 128 s. (in Russian)

3. Voroshilov $V$. Toponimy Rossiyskogo Chernomor'ya (istoriya $\mathrm{i}$ etnografiya $\mathrm{v}$ geograficheskikh nazvaniyakh) [Toponyms of the Russian Black Sea (history and ethnography in geographical names)]. Maykop: OJSC Polygraphizdat “Adygea", 2007.264 p.: ill. (in Russian)

4. Gradostroitel'stvo Rossii KHKHI veka: sb. nauch. statey RAASN [Urban planning of Russia of the XXI century: Sat. scientific articles RAASN]. Moscow: RAASN, 2001. 268 s. (in Russian)

5. Dizayn: illyustr. slovar'-spravochnik [Design: illustration dictionary-reference book]. Moscow: Architecture-S, 2004.283 s.: ill. (in Russian)

6. Ermolaev $A$. O real'nosti professii arkhitektora-dizaynera [On the reality of the profession of architect-designer]. Moscow: Arkhitek-tour-S, 2004.208 s.: ill. (in Russian)

7. Efimov A. Tsvet + forma: iskusstvo 20-21 vekov: zhivopis', skul'ptura. instalyatsiya, lend-art, digital-artï [Color + form: art of 20-21 centuries: painting, sculpture. installation, land art, digital art]. Moscow: Buksmart. 2014. 615 s., ill. (in Russian)

8. Efremov $Y$. Tropami gornogo Chernomor'ya [The paths of the mountain Black Sea]. Moscow: State. publishing house geographer. literature, 1963. 404 s.: ill. (in Russian)

9. Zhelondievskaya L. Emotsii grafiki. Izobrazitel'nyye i vyrazitel'nyye vozmozhnosti graficheskikh Metaforicheskaya obraznost' v dizayne [Emotion graphics. Graphic and expressive graphic possibilities. Metaphorical imagery in design]. Moscow: MAAA, 2004.222 s .: ill. (in Russian)

10. Zherdev E. Metafora $\mathrm{v}$ dizayne [A metaphor in design: Textbook. Allowance. 2nd edition, revised and enlarged]. Moscow: Architecture-S, 2010. 464 s., ill. (in Russian)

11. Zaitsev A. [The science of color and painting]. Moscow: Art, 1986. 158 s.: ill. (in Russian) 
12. Ivyanskaya I. Mir zhilishcha [The world of home]. Moscow: Dograph. 2000. 297 s., ill. (in Russian)

13. Itten I. Iskusstvo tsveta [The Art of Color]. Moscow: D. Aronov, 2001. 96 s.: ill. (in Russian)

14. Kalinicheva $M$. Nauchnaya shkola ergodizayna VNITTE: predposylki, istoki, tendentsii stanovleniya: monogr [Scientific School of Ergoddesign VNIITE: Prerequisites, Sources, Formation Trends: Monograph]. Moscow: VNIITE; Orenburg: IPK GOU OGU, 2009.368 s., ill. (in Russian)

15. Kirienko I. [Design culture of regional environmental design: Textbook. The allowance]. Sochi: RIC FSBEI HPE "SSU", 2014. 116 s. (in Russian)

16. Kiriyenko I., Novikov A. Preyemstvennost' v sisteme nepreryvnoy podgotovki budushchikh dizaynerov. Metod «Klyuch» [Continuity in the system of continuous training of future designers. The Key Method]. Moscow-Sochi: Scientific-Design Center M. Kalinicheva LLC "Technical Aesthetics", 2010. 125 s., ill. (in Russian)

17. Kiriyenko I., Kiriyenko Yu. Morfologicheskiye osobennosti regional'noy prirodnoy sredy Prichernomor'ya kak tvorcheskaya osnova kreativnogo dizayna [Morphological features of the regional natural environment of the Black Sea region as a creative basis for creative design: Textbook]. Sochi: RIC SGUTiKD, 2011. 104 s.: ill. (in Russian)

18. Kirienko I. Preyemstvennaya bezbar'yernaya podgotovka dizaynera v usloviyakh regional'noy kul'tury (na primere g. Sochi) [Continuous barrier-free training of the designer in the conditions of regional culture (for example, Sochi): Abstract for the degree of candidate of art history. 17.00.06 - Technical aesthetics and design]. Moscow: MGHPA im. S.G. Stroganova, 2011. 24 s. (in Russian)

19. Kiriyenko I., Makhova T, Bykadorova E.Y Obshchestvennyy ob"yekt v srede. Vystavka [Public facility in the environment. Exhibition. Textbook]. Sochi: RIC SSU. 2013. 56 s. (in Russian) 
20. Klee P. Pedagogicheskiye eskizy [Pedagogical sketches]. Moscow: D. Aronov, 2005. 71 s.: ill. (in Russian)

21. Kuryerova $G$. Ekologiya predmetnogo mira kak strategiya dizayna $\mathrm{v}$ postindustrial'nyy period [Ecology of the subject world as a design strategy in the post-industrial period]. Moscow: VNIITE. 2008.131 s. (in Russian)

22. Lonshakova N., Solodko A. Prirodnoye i istoriko-kul'turnoye naslediye Khostinskogo rayona goroda Sochi [Natural and historicalcultural heritage of the Khostinsky district of Sochi]. Sochi: Popular Encyclopedia of the Sochi Black Sea Region, 2007. 111 s.: ill. (in Russian)

23. Mel'nikov $V$. Myslit' risunkom [Think in the picture]. Ufa: Oil and Gas Business, 2007. 102 s.: ill. (in Russian)

24. Mikhailov S. Firmennyy stil' kak sredstvo vyrazheniya «istoricheskoy pamyati» goroda // [Corporate identity as a means of expressing the "historical memory" of the city] // Materials of the 12th All-Russian Conf. of main artists and chief designers of cities. Moscow: Union of Designers of Russia, 2009. Ss. 9-12. (in Russian) 25. Mikhailov S., Mikhailova A. Osnovy dizayna: ucheb. dlya vuzov [Fundamentals of Design: textbook for universities], ed. CM. Mikhailova. Kazan': "Design Quarter", 2008.288 s., ill. (in Russian)

26. Polukhina T. Istoriya Sochi v otkrytkakh i vospominaniyakh [The history of Sochi in postcards and memories]. Moscow: MZ: Progress. 2009. 252 s., ill. (in Russian)

27. Sidorenko $V$. Estetika proyektnogo tvorchestva [Aesthetics of design creativity]. Moscow: VNIITE, 2007. 135 s. (in Russian)

28. Tekhnicheskaya estetika i dizayn: Slovar' [Technical aesthetics and design: Dictionary]. Moscow: Academic project; Kultura, 2012 .- 356 s. (in Russian)

29. Shevelev I. Vizual'nyye i chislovyye obrazy real'nogo mira. Osnovy garmonii [Visual and numerical images of the real world. The basics of harmony]. Moscow: Luch, 2009. 335 s.: ill. (in Russian) 